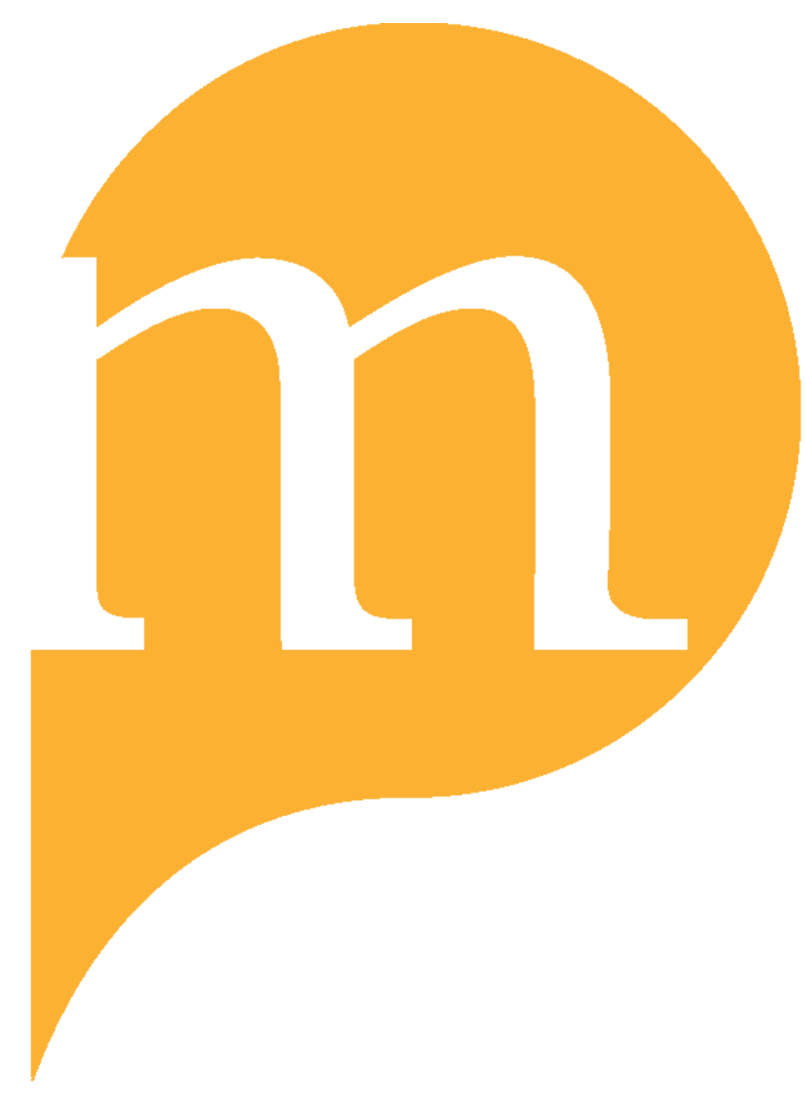

PROJECT MUSE 


\title{
Local, National, and International Determinants of Truth Commission: The South Korean Experience
}

\author{
Hun Joon Kim*
}

\begin{abstract}
In recent years, the number of truth commissions in countries around the world has continued to increase, and their scope and functions have become much broader. There is, however, still a need for a comprehensive theoretical framework that will enable scholars to explain the truth commission phenomenon. In this article, I will outline a new theoretical framework that combines social movement theory and transnational advocacy networks theory. I will then apply this framework to the South Korean truth commission experience, and analyze in detail the process that enabled local activists to successfully push for the creation of the first South Korean truth commission in 2000. Based on the South Korean case, I find that, first of all, important national and international factors would not have come into play if not for the persistent struggle of local activists. Second, I find that local activists were able to make optimal use of these national and international opportunity structures to pursue their goals through various timely and effective strategies.
\end{abstract}

* Hun Joon Kim is a Research Fellow in the Griffith Asia Institute and Centre for Governance and Public Policy at Griffith University. His research interests are international human rights, transitional justice, and international norm diffusion. He is the author of several journal articles published in Journal of Peace Research, International Studies Quarterly, the International Journal of Transitional Justice, Global Governance, and the Journal of Human Rights. $\mathrm{He}$ is currently completing a book manuscript, "The Massacres at Mt. Halla: Sixty Years of Truth-Seeking in South Korea."

I would like to gratefully acknowledge comments and suggestions from Kathryn Sikkink, Michael Barnett, John Freeman, Mary Dietz, Helga Leitner, as well as the financial support of the Australian Research Council. 


\section{INTRODUCTION}

The Jeju 4.3 events were a series of armed uprisings and counterinsurgency actions that occurred between 1947 and 1954 in Jeju Province, which is the largest island in the southernmost part of South Korea. ${ }^{1}$ The counterinsurgency strategy was extremely brutal, involving mass arrests and detentions, forced relocations, torture, indiscriminate killings, and many large-scale massacres of civilians. "The conflict resulted in an estimated 15,000 to 30,000 deaths, which corresponded to 10 percent of the total population of Jeju in 1947."2 In 2000, the government established the National Committee for Investigating the Truth about the Jeju 4.3 Events and Recovering the Honor of the Victims (Jeju Commission). The commission is still in progress at the time of writing, but is scheduled to end in the near future. To date, the commission has identified 15,093 victims, of whom 10,729 (71 percent) were killed, 3,920 (26 percent) were missing, and 444 (3 percent) were injured or imprisoned. Of the individual cases, 78 percent were attributed to state agents such as the police, military, and paramilitary groups, and 12 percent to communist guerrillas. Most victims were males in their teens and twenties (57 percent), but 35 percent were either female or aged under ten or over sixty, a fact that indicates the indiscriminate nature of the killings. In addition, the commission identified 32,403 family members affected by the events. ${ }^{3}$

Although the enormous civilian death toll was unprecedented, the massacres were systematically hidden from the general public, and the demand for truth and justice was completely suppressed over forty years of dictatorial and authoritarian rule. Following democratization in 1987, local students and scholars, social activists, and journalists openly established a movement to reveal the truth about the civilian massacres, to hold those responsible accountable, and to restore the honor of the victims. After thirteen years of sustained grassroots advocacy, the Jeju Commission-the first truth commission in South Korea-was established under President Kim Dae Jung. ${ }^{4}$

1. Major historical events in South Korea are remembered by the date on which they occurred. For example, the Korean War (1950-1953), which broke out on 25 June 1950, is referred to as the "6.25 War." Within this tradition, a series of armed conflicts in Jeju, triggered by a surprise attack by communist guerrillas on 3 April 1948, is commonly referred to as the Jeju 4.3 events. Thus, the Jeju 4.3 events differ from one-off events such as the 1972 "Bloody Sunday" shootings in Northern Island.

2. Hun Joon Kim, Seeking Truth after 50 Years: The National Committee for Investigation of the Truth about the Jeju 4.3 Events, 3 INT'L J. TRans'L Just. 407 (2009) [hereinafter Seeking Truth after 50 Years], available at http://ijtj.oxfordjournals.org/content/3/3/406.full.pdf. Accord Provincial 4.3 Committee, Report of the Jeju 4.3 Victims (Jeju Provincial Council ed., 1997).

3. Kim, Seeking Truth after 50 Years, supra note 2, at 411. Accord Jeju Commission, Official Report of the National Committee for Investigation of the Truth about the Jeju 4.3 Events (2003).

4. For Korean names, the family name is presented first (e.g. Kim), followed by the first name, which usually consists of two words (e.g. Dae Jung) without a hyphen. 
The commission had three mandates: to investigate and reveal the truth, to screen and identify victims, and to restore the honor of the victims.

The commission's report was published in 2003. This prompted an official apology from President Roh Moo Hyun, the first presidential apology for the abuse of state power in South Korea. Moreover, President Roh visited Jeju on 3 April 2006, where he participated in a memorial service for the victims and issued a further apology for the events. ${ }^{5}$ The government has also revised history textbooks and official documents to incorporate material about the state violence and civilian massacres. Since then, the commission has focused on screening victims, exhumation of mass murder sites, and carrying out various commemoration projects, including the establishment of the permanent Jeju 4.3 Peace Foundation and Jeju 4.3 Memorial Park in 2008. The decade-long work of the commission is generally viewed as a success, and a dozen other truth commissions have been created in the wake of the Jeju Commission. ${ }^{6}$

The Jeju Commission has gone largely unnoticed by scholars and practitioners around the world. However, the South Korean experience poses an important question not only for the study of truth commissions in particular, but also for the study of transitional justice more generally. Earlier truth commissions like those in Latin America and Africa were set up immediately after a political transition. Recent commissions, however, are increasingly investigating more historically remote cases, as we have witnessed in Uruguay, Panama, and Paraguay. ${ }^{7}$ Why is there a growing tendency for states to create truth commissions to investigate human rights violations in the distant past? The question of delayed transitional justice is not limited to the case of truth commissions, because a similar pattern exists in recent criminal prosecutions. In recent years, state officials in Argentina, Cambodia, and Uruguay have been arrested, prosecuted, and convicted long after their crimes were

5. Roh Mu Hyun, Statement of the President on the Jeju April 3 Incident (31 Oct. 2003), available at http://www.jeju43.go.kr/english/sub07.html; Jeju Commission, supra note 3.

6. The Jeju Commission provided guidance and expertise to the Presidential Truth Commission on Suspicious Deaths $(2000,2003)$ and the Truth and Reconciliation Commission (2005). In addition, many commissions such as the Special Committee for the Investigation of Forced Labor under Japanese Rule and the Presidential Truth Commission on Suspicious Military Deaths were created. Interview with Kim Jong Min, Reporter, Jemin-Ilbo, responsible for interviewing and writing the special reports, in Seoul, Korea (2 Dec. 2011); see also Truth and Reconciliation Commission Republic of Korea, The Final Report of the Truth and Reconciliation Commission, Republic of Korea $\S$ I. The History and Activities of the Commission \& Policy Recommendation, at 8-13 (2010).

7. Geoff Dancy, Hun Joon Kim \& Eric Wiebelhaus-Brahm, The Turn to Truth: Trends in Truth Commission Experimentation, 9 J. Hum. Rts. 45, 57-58 (2010); Priscilla B. Hayner, Unspeakable Truths: Transitional Justice and the Challenge of Truth Commissions 63, 251-52 (2d ed. 2011). 
committed. ${ }^{8}$ This new tendency to investigate past human rights violations has even affected countries such as the United States, Canada, and Australia. ${ }^{9}$

In this article, this question is answered by applying social movement theory and transnational advocacy networks theory. These theories are applied to the South Korean experience and analyze in detail the process whereby local activists successfully created the Jeju Commission after thirteen years of advocacy. It is found that strong and persistent local activism, driven by local students and scholars, social movement activists, and journalists was the single most important factor in the establishment of the commission. Certainly, there were a series of significant domestic (democratic consolidation, sympathetic political leaders, and national media) and international (diffusion, international norms, and pressure from international civil society) factors. Nevertheless, these important domestic and international factors would not have come into play if not for the persistent struggle of local activists. Further, local activists capitalized on these domestic and international opportunities to create a truth commission through various timely and effective strategies.

\section{A THEORETICAL FRAMEWORK}

Since the creation of a truth commission is mainly a domestic political process influenced by international factors, theories of political science and international relations are relevant. ${ }^{10}$ Social movement theory and transnational advocacy networks theory provide useful conceptual frameworks for capturing the process of truth commission establishment because the demand for truth usually takes the form of advocacy. Three elements were considered: agents (advocacy networks), structures (domestic and international), and strategic interaction between agents and structures.

\section{A. Agent: Advocacy Networks}

Advocacy networks are "forms of organization characterized by voluntary, reciprocal, and horizontal patterns of communication and exchange" and are

8. Dancy, Kim \& Wiebelhaus-Brahm, supra note 7, at 45-47; HAYNeR, supra note 7 , at 204-07, 251.

9. Andrew Gunstone, Unfinished Businesses: The Australian Formal Reconciliation Process (Australian Scholarly Publishing 2007); HAYNER, supra note 7, at 62, 72-73; Frequently Asked Questions, The Greensboro Truth and Reconciliation Commission, available at http:// www.greensborotrc.org/faq.php.

10. See generally Comparative Perspectives on Social Movements (Doug McAdam, John D. McCarthy \& Mayer N. Zald eds.,1996); Restructuring World Politics: Transnational Social Movements, Networks, and Norms (Sanjeev Khagram, James V. Riker \& Kathryn Sikkink eds., 2002); Margaret E. Keck \& Kathryn Sikkink, Activists Beyond Borders: Advocacy Networks in International Politics (1998); Transnational Social Movements and Global Politics: Solidarity Beyond the State (Jackie Smith, Charles Chatfield \& Ron Pagnucco eds., 1997). 
characterized by "fluid and open relationships among committed and knowledgeable actors working in specialized issue areas . . . to promote causes, principled ideas, and norms." 11 Scholars have identified several key actors that facilitate the establishment of truth commissions, such as associations of victims' families, human rights nongovernmental organizations (NGOs), student activists, lawyers, intellectuals, and the media. ${ }^{12}$ Advocacy networks are usually motivated by their values and beliefs, such as empathy, altruism, or ideational commitment, and their goal is to secure the establishment of a truth commission by influencing the government and the general public. ${ }^{13}$

\section{B. Structures: Domestic and International}

Structures are those consistent "dimensions of the political environment that provide incentives [for or constraints on people undertaking] collective action." ${ }^{14}$ Structures constitute a powerful set of constraints and opportunities that affect advocacy networks. Sometimes, structures facilitate the formation and development of the advocacy and other times structures limit its development. There are generally two types of structures affecting advocacy networks: domestic and international. Scholars of transitional justice have pointed to various domestic structures that serve to facilitate or constrain advocacy networks, such as mature democracy, sympathetic political leaders, national media coverage, the government's respect for human rights, the power balance between old and new elites, and economic conditions. ${ }^{15}$ Likewise, they have stressed several international structures: the develop-

11. KECK \& SIKKINK, supra note 10 , at 8 .

12. See generally David Pion-Berlin, To Prosecute or to Pardon? Human Rights Decisions in the Latin American Southern Cone, 16 Hum. RTs. Q. 105 (1994); Elin Skaar, Truth Commissions, Trials: Or Nothing? Policy Options in Democratic Transitions, 20 THIRD World Q. 1109 (1999); David Backer, Civil Society and Transitional Justice: Possibilities, Patterns and Prospects, 2 J. Hum. RTs. 297 (2003); Mô Bleeker \& Jonathan Sisson, Dealing with the Past: Critical Issue, Lessons Learned, and Challenges for Future Swiss Policy (Swisspeace, Working Paper No. 2, 2004), available at http://www.swisspeace. ch/publications/working-papers-archive.htm/\#c881.

13. Martha Finnemore \& Kathryn Sikkink, International Norm Dynamics and Political Change, 52 INT'L ORG. 887, 898 (1998).

14. Sidney Tarrow, Power in Movement: Social Movements and Contentious Politics $76-77$ (2d ed. 1998).

15. See generally Tricia D. Olsen, Leigh A. Payne \& Andrew G. Reiter, Transitional Justice in Balance: Comparing Processes, Weighing Efficacy (2010); Samuel P. Huntington, The Third Wave: Democratization in the Late Twentieth Century (1991); Luc Huyse, Justice after Transition: On the Choices Successor Elites Make in Dealing with the Past, 20 L. \& Soc. Inquiry. 51 (1995); Carlos Santiago Nino, Radical Evil on Trial (1996); From Dictatorship to Democracy: Coping With the Legacies of Authoritarianism and Totalitarianism (John H. Herz ed., 1982); Jorge Correa Sutil in collaboration with Francisco Jiménez, "No Victorious Army Has Ever Been Prosecuted . . .": The Unsettled Story of Transitional Justice in Chile, in TRANSITIONAL Justice and the Rule of Law in New Democracies 123 (A. James McAdams ed., 1997); Jon Elster, Closing the Books: Transitional Justice in Historical Perspective (2004). 
ment and effect of international ideas and norms such as human rights or individual accountability, the diffusion of neighbors' experience, and pressure from international organizations and international civil society. ${ }^{16}$

\section{Strategic Interactions}

Advocacy networks pursue various strategies in order to achieve their intended goals within given domestic and international structures. Margaret Keck and Kathryn Sikkink provide a useful categorization of the strategies used by advocacy networks: information politics, symbolic politics, leverage politics, and accountability politics. Information politics refers to the ability to quickly and credibly generate politically useful information and move it to where it will have the most impact; symbolic politics refers to the ability to call upon symbols, actions, or stories that make sense of a situation for an audience; leverage politics refers to the ability to call upon powerful actors to affect a situation in which weaker members of a network are unlikely to have influence; and accountability politics refers to the effort to hold powerful actors to their previously stated policies or principles. ${ }^{17}$

\section{ADVOCACY NETWORKS IN SOUTH KOREA}

The path towards the establishment of the first truth commission in South Korea was a long and painstaking journey. The Rhee Syng Man dictatorship, which was responsible for the massacres, lasted six more years before Rhee was ousted out in 1960. Although a short-lived democracy followed, it was soon overthrown in a coup by Park Chung Hee in 1961. No one publicly spoke of the Jeju 4.3 events under these dictatorial regimes for over thirty years, and critical evidence of the massacres was systematically destroyed..$^{18}$ The suppression continued when Chun Doo Hwan seized power in another coup after the death of Park in 1979. Chun's authoritarian regime lasted until 1987, when his proclaimed successor Roh Tae Woo agreed to direct presidential elections.

16. Hayner, supra note 7; Kathryn Sikkink, The Justice Cascade: How Human Rights Prosecutions Are Changing World Poltics 20-24 (2011); Chandra Lekha Sriram, Revolutions in Accountability: New Approaches to Past Abuses, 19 Am. U. INT'L L. Rev. 301, 314-18 (2003); Naomi Roht-Arriaza, Civil Society in Processes of Accountability, in Post-Conflict Justice 97, 97-98 (M. Cherif Bassiouni ed., 2002); Martha Minow, Between Vengeance and Forgiveness: Facing History after Genocide and Mass Violence 9, 23 (1998); Douglass W. Cassel, Jr., International Truth Commissions and Justice, 5 Aspen INST. Q. 69 (1993).

17. KECK \& SIKKINK, supra note 10 , at 16 .

18. Kim, Seeking Truth after 50 Years, supra note 2, at 407; see also Jeju Commission, Jeju SASAm Sageon Jinsang Josa Bogoseo (Report of the Truth About the Jeju 4.3 Events), at 36 (2003); Dong-Choon Kim, The Long Road toward Truth and Reconciliation, 42 CRITICAL AsIAN Stud. 535 (2010). 
Strong and persistent local advocacy was the single most important factor in the process of seeking transitional justice. The role of local advocacy was central and indispensable to the establishment of the Jeju Commission. Various actors played a significant role in different phases of the activism, but three local actors - students and scholars, social movement activists, and journalists-played the most important and consistent roles in the movement. These actors were mostly motivated by the pursuit of truth, a sense of justice, compassion and empathy, historical consciousness, and conscience. They continued to believe strongly in their cause despite manifest and severe suppression and surveillance. In addition, other actors such as victims, writers and artists, local politicians, and national political leaders played a vital role during particular phases.

Of the three crucial actors, students-and to some extent, scholars and intellectuals-were the ones that courageously made the first move and took the initiative in the movement, thus inspiring the other actors. A small group of students at Jeju National University initiated the first public investigation of the massacres in 1960, during a short period of democracy. ${ }^{19}$ Inspired by the students' activism, a local newspaper, the Jeju-Shinbo, began the first province-wide investigation of the massacres, and this became a steppingstone for later government investigations. Before and after democratization, students were among a handful of social groups that openly advocated transitional justice and organized public demonstrations. In 1993, students began a petition movement, by submitting a signed petition to the legislature calling on it to investigate and act upon the civilian massacres. ${ }^{20}$ This was a significant move, marking the inclusion of what had previously been a local issue on the national political agenda. ${ }^{21}$ Finally, the student movement served as an important locus for nurturing major activists and sympathetic researchers who devoted their full energies to the movement.

Second, local social movement activists and organizations formed strong advocacy networks in Jeju. During and after the transition to democracy, many organizations were created to focus on labor, human rights, national unification, the environment, farmers, women, social justice, culture, political reform, and transitional justice issues. Since 1989, these groups have jointly organized an annual memorial service and art festival every April in order to commemorate the Jeju 4.3 events. Meetings to plan these commemorative activities provided an opportunity for local activists to meet and share information, expertise, and strategies. This collaboration created "a common

19. Interview with Lee Moon Kyo, leader of the student movement at Jeju National University, in Jeju, Korea (22 Apr. 2006).

20. Interview with Oh Young Hoon, Chairperson of the Jeju Student Association in 1993, in Jeju, Korea (2 May 2011).

21. Interview with Byun Jeong II, Congressman representing Jeju in 1993 and presented students' petition to the National Assembly, in Jeju, Korea (10 May 2011). 
identity for the social movement groups and enhanced further collaboration and communication among groups." ${ }^{22}$ In the process, these organizations developed a strong sense of solidarity that centered on the issue of the civilian massacres. In the later period of advocacy, local activists were able to work closely together by creating an overarching organization to maximize the effectiveness of the movement. In 1998, local activists successfully publicized their cause by organizing a year-long $50^{\text {th }}$ anniversary commemoration of the Jeju 4.3 events incorporating art, traditional rituals, cultural projects, testimonial hearings, and academic conferences. The following year, activists pursued an intensive political campaign to enact special legislation that provided redress for the civilian massacres. During the course of that year, local activists led the national campaign to press for legislation, as well as organizing weekly rallies in Seoul and Jeju. ${ }^{23}$

Third, local journalists played a significant role in the advocacy process. As noted earlier, it was a local newspaper, the Jeju-Shinbo that initiated the first province-wide fact-finding project in 1960, inspired by the student activists. Although the newspaper uncovered only one-tenth of the total number of victims that were eventually identified in 2003, it revealed an important aspect of the massacres by confirming that the majority of the killings were committed by the military and the police. ${ }^{24}$ After democratization in 1987, the Jemin-Ilbo published 456 special reports on the Jeju 4.3 events and civilian massacres over nine years, based on interviews with more than 3,000 witnesses. This extensive newspaper coverage played an indispensable role in the advocacy process by publicizing the massacres and establishing the Jeju 4.3 events and massacres as key social issue. ${ }^{25}$ Moreover, the coverage was remarkably effective in encouraging victims, who had been stigmatized as communists and intimidated by the state violence and subsequent suppression, to actively participate in the movement. ${ }^{26}$ Finally, the knowledge and expertise gained in the course of the journalists' investigations laid the foundations for the official report of the Jeju Commission. Both Yang Jo Hoon and Kim Jong Min, who played a significant role in writing special reports for the Jemin-IIbo, later worked in key posts for the Jeju Commission and transmitted their expertise and knowledge to the commission.

22. Interview with Oh Seung Kook, Secretary General of the 4.3 Research Institute and former President of the Jeju Cultural Movement Association, in Jeju, Korea (7 Apr. 2006).

23. Jeju Commission, supra note 18, at 38-39.

24. "By 10th, 1,259 applications arrived; 1,172 male victims and 285 female victims, victims from 10-day-old to 93-year-old." JEJu-SHINBO, 13 June 1960, in JEJU COMMISSION, JeJU 4.3 Sageon Jaryojip 3: Sinmun-pyeon (Jeju 4.3 Events Archive, Vol. 3: Newspapers), at 337-38 (2002).

25. Gui-Suk Kwon, Gieok-eui Jeongchi: Daeryang Haksal-eui Sahoejeok Gieok-gua Yeoksajeok Jinsil (Memory and Politics: Social Memory and Historical Truth of Massacres) 198 (Munhakgua Jiseong ed., 2006).

26. Interview with Kim Jong Min, Reporter, Jemin-I/bo, responsible for interviewing and writing the special reports, in Seoul, Korea (25 May 2006). 
In the remainder of this article, I examine how the local advocacy networks of students, activists, and journalists examine how the movement advanced in the face of the domestic and international structures. For my study, I chose three domestic (democratic consolidation, sympathetic political leaders, and national media) and international (diffusion, international norms, and pressure from international civil society) structures that influenced the establishment of the truth commission. I address the issue of how advocacy networks contributed to creating these conducive and open structures in the first place. In addition, I show how advocacy networks interpreted, reframed, and interacted with these domestic and international structures in order to make effective use of the opportunities to further the movement, employing various strategies - information, symbolic, leverage, and accountability politics.

\section{LOCAL ADVOCACY IN THE DOMESTIC STRUCTURE}

\section{A. Democratic Consolidation}

Although there were a few sporadic and individual attempts to address the Jeju 4.3 events and civilian massacres over the years, such efforts were systematically suppressed by the dictatorial and authoritarian regimes of the day. During this period efforts to question, remember, and seek justice for the unjustifiable state violence were made on several occasions by family members of the victims, students, journalists, and a few courageous artists and writers. The most meaningful breakthrough came in 1978 when Hyun Ki Young, a writer from Jeju, published a short story about the Bukchon massacre, which formed part of the Jeju 4.3 events. ${ }^{27}$ This was a critical moment in transitional justice history because it marked the first public mention of the Jeju 4.3 events and civilian massacres after three decades of total silence. However, the government suppression and surveillance again intensified after this, and there was no further mention of the Jeju 4.3 events until the democratic transition. ${ }^{28}$

South Korea's transition to democracy in 1987 brought a significant change in the domestic political structure. In 1991, the central government began to transfer administrative and legislative power to local governments and councils by reviving the regional self-governance system. At the very first meeting of the Jeju local council, the civilian massacres during the Jeju

27. Gi-Yeong Hyun, Suni Samchon (Aunt Suni) (Changbi Publishers, Inc. 1979).

28. Jong Min Kim, Fifty Years after 4.3, in Study of Jeju 4.3341 (Jeju 4.3 Research Institute ed., 1999). 
4.3 events were raised as the first agenda item by a local council member. The members of the council were sensitive to local people's demands on this issue because they were all elected representatives of local cities and counties, and it was impossible to find any city and county that had not been affected by the Jeju 4.3 events. The local people's demand for truth and justice was therefore able to be effectively channeled through these local council members. Local advocacy networks made the most of this opportunity to advance the transitional justice movement. As a result, the Provincial 4.3 Committee, a special committee to address the Jeju 4.3 events and civilian massacres, was set up in 1992 under the local council. The Provincial 4.3 Committee, which had three terms up to 1999, played a critical role by conducting an official investigation, encouraging ideologically opposed groups to cooperate, and leading the province-wide petition movement. ${ }^{29}$

The transition to democracy was certainly a precondition for the movement. A maturing democracy provided an open and favorable domestic structure for transitional justice advocacy, and the creation of the Provincial 4.3 Committee was made possible mainly by the decentralization of political power. However, if we take a closer look at the process, we can see the centrality of the local advocacy networks. Democratization and the decentralization of power was itself the result of a long and painful struggle for democracy by various social movement activists across the country, including those in Jeju. In other words, the fact that favorable space opened up with democratization is not something that should be taken as a matter of course; rather, it was the result of persistent local activism. The core members of the advocacy networks — students, activists, and journalists — were all heavily involved in the democratization movement. In 1987 and even before, local activists and organizations were part of an underground pro-democracy movement under the authoritarian government of Chun Doo Hwan. Thus, democracy was not an exogenously given structure but a condition made possible by local advocacy networks.

Second, the combined efforts of local research and social movement organizations and the media were invaluable in creating the Provincial 4.3 Committee within the Jeju local council. Although the civilian massacres were raised as the first agenda item at the first plenary session of the local council, members of the council were still hesitant to take decisive action. Due to the social stigma associated with the Jeju 4.3 events, few members openly advocated for transitional justice. ${ }^{30}$ The decisive blow came from civil society and social movement groups. The Jeju 4.3 Research Institute and the Jemin-Ilbo jointly announced the existence of the Darangshi cave, where

29. Provincial 4.3 Committee, supra note 2.

30. Interview with Kim Young Hoon, Chairperson of the first and second term Provincial 4.3 Committees, in Jeju, Korea (7 Apr. 2006). 
they had discovered the skeletal remains of eleven victims, including women and children, who had taken refuge in the cave but had been killed by the military and police. This event was widely publicized in local and national news media and, on the same day, local council members officially agreed to establish the Provincial 4.3 Committee. ${ }^{31}$ It is clear that local activists and journalists were influential in creating the critical momentum for subsequent advocacy. The activists used strategies of information and symbolic politics. The cave was discovered in December but kept under wraps for three months to maximize the impact of the announcement by timing it just before 3 April $1992 .^{32}$ In the meantime, activists gathered as much information as possible on the cave, with the assistance of local media and other experts such as doctors, lawyers, and anthropologists. The activists knew the importance of the cave and prepared for the announcement for three months in order to achieve the desired effect.

With the discovery of the cave, the activists were in possession of consequential information that had the power to change the path of their advocacy, and they mobilized this information at just the right moment. In addition, they understood, and were able to effectively utilize the symbolic significance of the cave. Kim Dong Man, a professor who was a Secretary General of the Jeju 4.3 Research Institute at the time of discovery of the cave, argued that the cave represented and symbolized the failure to address the civilian massacres themselves:

Fifty year-old corpses still lying in the cold Darangshi cave unattended. . . This is exactly the same as the status of the Jeju 4.3 events and civilian massacres, which have been suppressed and forgotten for over [fifty] years. The corpses in the cave are a symbol that shows that the Jeju 4.3 events and civilian massacres have not been resolved. ${ }^{33}$

Due to its importance as a symbol of the Jeju 4.3 events and transitional justice advocacy, a replica of the Darangshi cave has been created in the center of the Jeju 4.3 Memorial Park.

Finally, advocacy networks effectively supported the activities of the Provincial 4.3 Committee. Without the support and assistance of civil society and activist groups, the Provincial 4.3 Committee would not have been able to make such an important contribution to the cause. One reason for this is that it was difficult to recruit members for the committee's first term.

31. Angela Kim, Darangshi Cave Unearths Yet More Jeju Massacre Tragedy, The Jeju WeEkLY, 23 Mar. 2012; Kim, supra note 2, at 407; see also Special Reporting Team, Discovered Eleven Skeletal Remains of the 4.3 Victims, Jemin-ILBO, 2 Apr. 1992; Heo Ho Joon, Discovery of 11 Skeletal Remains of the 4.3 Victims, HaNKYOREH, 2 Apr. 1992.

32. Interview with Kang Chang II, Board Member of the Jeju 4.3 Research Institute in 1992, in Jeju, Korea (8 May 2011).

33. Interview with Kim Dong Man, Former Secretary General of the Jeju 4.3 Research Institute who discovered the cave, in Jeju, Korea (12 Apr. 2006). 
Although most council members supported the idea of transitional justice, they did not want to be directly involved in the process. However, the situation changed dramatically when the seven committee members from the first term were all reelected in a landslide, with the strong support of victims and activists. ${ }^{34}$ Similarly, the first chairperson of the Provincial 4.3 Committee, Kim Young Hoon, was later elected as mayor of Jeju City with the support of social movement organizations and victims' associations. ${ }^{35}$ In addition, major projects of the Provincial 4.3 Committee-the official investigation, united memorial service, and petition movement-were all carried out by local social movement organizations. The information, expertise, and personnel supplied by the local advocacy networks were a main element in the work of the Provincial 4.3 Committee.

\section{B. Sympathetic Leader}

The second most important factor in the opening up of the domestic structure was the inauguration of President Kim Dae Jung in 1998. Although Kim Dae Jung had retired from politics after being defeated by Kim Young Sam in the 1992 presidential election, he returned to win the 1997 election. Kim Dae Jung's political constituency was based in Jeolla and Jeju provinces, and he pledged several times during the campaign to address the issue of the Jeju massacres. Certainly, Kim Dae Jung, with his strong commitment to human rights, played a significant role in transitional justice advocacy. Like mature democracies, sympathetic and committed leaders create a structure conducive to advocacy. The inauguration of Kim Dae Jung was a precondition for the creation of the Jeju Commission. However, closer examination reveals that although it was a necessary condition, it was not a sufficient condition-if not for the pressure and input of local activists, even Kim Dae Jung's resolve would not have been sufficient to create the truth commission.

The first evidence for this contention can be found in Kim Dae Jung's first public statement on the Jeju 4.3 events in 1987 when he visited Jeju during his presidential campaign, immediately after democratization:

People in Jeju have suffered the tragedy of the Jeju 4.3 events. I will be with you in your regrets, pain, and hope. The military and authoritarian governments also falsely accused me of being a communist and I myself am a victim. If I am in power, I will investigate the truth of the Jeju 4.3 events, where people have been falsely accused of being communists, and will restore the honor of the victims. ${ }^{36}$

34. Interview with Kim Young Hoon, supra note 30.

35. Yang Seong Cheol, Newly-Elected Major of Jeju City Kim Yeong Hun, Joongang-Lıo, 6 June 2006.

36. Cited in Kim, supra note 28. 
He further pledged during his presidential campaign in 1992 that he would enact special legislation. Before he was elected in 1998, Kim Dae Jung made 12 public pledges on this issue, and these statements later provided a highly useful and effective tool that enabled activists to exert pressure on politicians, party members, and members of congress. ${ }^{37}$ All of these pledges stemmed from the 1987 statement, and one local intellectual, who had long been involved with the movement, played a significant role.

Professor Ko Chang Hoon was responsible for drafting Kim Dae Jung's Jeju address in 1987, and for the decision to include the Jeju 4.3 events and massacres in the statement. ${ }^{38}$ According to Professor Ko, Professor Lee Moon Young, a professor at Korea University, sent him a note the day before Kim Dae Jung's arrival in Jeju asking him to draft a campaign address that would stand out from those of the other candidates. Professor Ko, who had been studying the Jeju 4.3 events, firmly believed that these events should be included in Kim Dae Jung's address. When Kim Dae Jung delivered his address, it caused a sensation, not only among people in Jeju but also in Seoul. Thus, Kim Dae Jung's first presidential pledge was the result of the activism and research of one intellectual. Even though it was Kim Dae Jung himself who promised to deliver truth and reparations for the victims of the Jeju 4.3 events, the cumulative efforts and research of local activists were an indispensable prerequisite for his pledge. Even this considerable commitment from a sympathetic leader was made possible by local activism.

Even under Kim's tenure, constant activism and persistent demands from civil society played a more important role than Kim Dae Jung's political will and promises alone. This is because leaders can-either intentionally or unintentionally - forget or fail to follow through with their promises. In addition, it is possible that the measures adopted by national politicians may fall short of the expectations of the victims and activists. Kim Dae Jung spent the first three years of his presidency rebuilding the Korean economy in the aftermath of the 1997 Asian financial crisis. Economic recovery was the primary goal of his administration at that time, and it was successful in avoiding the possibility of state bankruptcy. ${ }^{39}$ By contrast, the transitional justice measures Kim Dae Jung and his party introduced during the first two years of his tenure-establishing a special committee within the ruling party - fell far short of the expectations of people in Jeju. In addition, the special committee's only activities during its first year were two public hearings, which greatly disappointed the victims and activists. ${ }^{40}$

37. Kim, Seeking Truth after 50 Years, supra note 2 .

38. Interview with Ko Chang Hoon, Professor Jeju National University and former Director Jeju 4.3 Research Institute, in Jeju, Korea (24 Mar. 2006).

39. The Nobel Foundation, Kim Dae-jung-Biography 2012, available at http://www.nobelprize.org/nobel_prizes/peace/aureates/2000/dae-jung-bio.html.

40. Kim, Seeking Truth after 50 Years, supra note 2, at 418. 
From that time local advocacy networks actively pursued a political campaign to enact special legislation to create a truth commission. The Jeju Commission would not have been established if the activists and victims had passively waited for Kim Dae Jung to take the next step. The process of transitional justice did not proceed smoothly, even with Kim Dae Jung's party in power. Despite persistent demands for special legislation to be passed, the ruling party only proposed to establish a special congressional committee, and even submitted a resolution to that effect. The ruling party's central organization even ignored the demands of its local branch for a change of policy on the Jeju issue. ${ }^{41}$ It was only through activism and lobbying that activists and victims were able to influence the policy of the ruling party and break the impasse. At every point, activists strategically employed Kim Dae Jung's public commitments, in order to force passive and uninterested politicians to move forward and take action, making this situation a good example of the accountability politics of advocacy networks. ${ }^{42}$

\section{National Media}

The mass media, especially the national media, played a significant role in publicizing the civilian massacres and bringing this neglected issue to public attention. The Jeju 4.3 events, which had long been taboo due to their association with communism, were addressed for the first time in the popular television drama series, The Eye of the Dawn, in 1992. Many interviewees have told me that the screening of these episodes was considered a "highly sensational event" in Jeju. ${ }^{43}$ It was sensational in three respects. First, the television series in question was a particularly popular one, which constantly had an audience rating of fifty percent or more. Second, the Jeju 4.3 events were the main theme of the drama across four episodes, which screened over a two-week period. Third, the Jeju 4.3 events were not portrayed in these episodes from the dominant anticommunist perspective; rather, the screenwriter had tried to treat both ideological perspectives fairly. In other words, the episodes touched on the Jeju 4.3 events not only as a communist rebellion but also in terms of human rights abuses and a democratic uprising, through the eyes of the characters. Some of the lines delivered by Jeju residents in the drama include: "We are facing either starving to death or

41. Id. at 418,421 .

42. Congresswoman Choo Mi Ae of the ruling party played a significant role in bringing the Jeju 4.3 events onto the national political agenda and urging the ruling party to honor its commitments. For more detail, see Kim, Seeking Truth after 50 Years, supra note 2, at 406, 418.

43. Interview with Park Chan Sik, Director of the Jeju 4.3 Research Institute, in Jeju, Korea (6 Apr. 2006). 
being beaten to death. Even a worm will turn"; "Why do the members of the rightist youth group use violence against us? The police are protecting and using these groups and there is an American at the top"; and "Will the government treat 300,000 Jeju residents as enemies simply to destroy a few communists?" 44 These words reflected a perspective that had not previously been aired in public arenas such as politics, media, or education. Due to the popularity of the show, the national news media started to show interest in the Jeju 4.3 events as well.

What made this initial television exposure possible? One answer lies in screenwriter Song Ji $\mathrm{Na}$, who had spent around four years at high school in Jeju. In an interview with a local newspaper, Song explained that she had a desire to tackle the Jeju 4.3 events as a screenwriter, but had considered it impossible to create an entire drama that focused exclusively on these events. Song, and later the show's producer, admitted that the flow of the drama had actually been compromised by the inclusion of the Jeju 4.3 events, which had not been discussed in the original novel on which the series was based. Nevertheless, both screenwriter and producer had decided to sacrifice the artistic values of the drama in order to reveal this historic injustice. ${ }^{45}$ This came through clearly in Song's interview:

People criticized me for raking up the tragic past. However, I thought that it was my duty as a screenwriter to address a past history of injustice, if it really existed. I believe the only way to prevent historical wrongs from repeating themselves over and over again in the future is through the investigation and thorough study of what went wrong. ${ }^{46}$

However, Song's will, vision, and desire were not the only contributing factors. Song has acknowledged that these episodes of the drama would not have been possible if not for the efforts of journalists from the Jemin-Ilbo, who provided the factual details on which the episodes were based. Thus, the programs were a collaborative effort between the local mass media and one courageous screenwriter.

44. Yeomyeong-eui Nundongja (Eye of Dawn) (Munhwa Broadcasting Corporation, Episodes 29-32, television show broadcast from 7 Oct. 1991 to 6 Feb. 1992).

45. Heo Young Bae, An Epic Drama: The Eye of the Dawn, Jemin-lıbo, 7 Nov. 1991.

46. Kim Jong Min, Jeju 4.3 Too Big To Fit in a TV Drama: Interview with Song Ji Na, JeminILBO, 7 Feb. 1992. 


\section{LOCAL ADVOCACY IN THE INTERNATIONAL STRUCTURE}

\section{A. Diffusion}

In my cross-national study of truth commissions worldwide, I found compelling evidence of the diffusion effect of the truth commission experience of neighboring countries. States are more likely to use truth commissions after democratization if such commissions have already been established by their neighbors. ${ }^{47}$ The diffusion factor is a crucial element of the international structure affecting the advocacy process. Good examples and effective strategies in a neighboring country with a similar history of human rights violations tend to open up a space for domestic advocacy, while negative or failed examples are likely to serve as a constraint on local advocacy. The Jeju case was influenced by the positive impact of the truth commission that had been established in Taiwan. ${ }^{48}$ Taiwan's so-called 2.28 events and transitional justice experience had a distinct impact on the path to the creation of the Jeju Commission.

The 2.28 events occurred under Chiang Kai-Shek's Kuomintang in 1947, when Taiwan was a peripheral island in the southern part of China that was inhabited by the Taiwanese aboriginal people. The crisis was sparked by the confiscation of cigarettes and money from an indigenous old woman in a street kiosk by a few policemen and government agents, on charges of illegal importation. When the old woman and her sons resisted, she was beaten to death by the police. ${ }^{49}$ The local Taiwanese were outraged and vehemently protested against the Chiang Kai-Shek regime. However, the government brutally suppressed the public protest, arguing that it had been instigated, planned, and supported by the communists on the mainland. However, in the course of the subsequent official investigation, scholars were unable to find any evidence that the protest had been ordered or instigated by the Chinese Communist Party; it was simply a protest against the unfair treatment of aboriginal Taiwanese, not a communist rebellion. ${ }^{50}$

As with the Jeju 4.3 events, the counterinsurgency strategies in Taiwan were extremely violent and resulted in the deaths of approximately 20,000

47. Hun Joon Kim, Expansion of Transitional Justice Measures: A Comparative Analysis of Its Causes, 26 (2008) (unpublished Ph.D. Dissertation, University of Minnesota).

48. Kim Jong Min, The Taiwanese 2.28 Events: A Similar Case to the Jeju 4.3 Events, JEMINILBO, 21 Apr. 1993.

49. Laurence Eyton, National Identity Formation in Settler Societies, in National ChenGCHI University Collection 128 (2008), available at http://nccur.lib.nccu.edu.tw/bitstre am/140.119/37472/10/92401510.pdf.

50. Lee Hsiao-feng, The Real Cause of the 228 Incident, TAIPE TIMES, 4 Mar. 2010, at 8, available at http://www.taipeitimes.com/News/editorials/archives/2010/03/04/2003467130. 
civilians. However, the Chiang Kai-Shek government declared martial law in Taiwan and the truth was concealed for more than forty years. With Taiwan's democratic transition in 1987, victims and activists demanded that the truth of the massacres be revealed, paving the way for reparations for the victims and their families. In 1995, five years before the establishment of the Jeju Commission, the Lee Teng-Hui government enacted legislation to investigate the massacres and make reparations to the victims. After a year-long investigation, the government announced that 18,000 to 20,000 victims had been killed and, most notably, declared that Chiang Kai-Shek himself had been responsible for issuing the order to kill civilians. In addition, the government declared 28 February a national memorial day to commemorate the 2.28 events and their civilian victims. ${ }^{51}$

The Taiwanese case was first publicized in South Korea by a local newspaper in Jeju, the Jemin-IIbo. ${ }^{52}$ The media followed the developments in Taiwan closely, and this case provided inspiration not only to activists but also to the general public. Many interviewees - both activists and victimsreferred to the Taiwanese massacres and transitional justice process. ${ }^{53}$ The Taiwanese experience was critical in stimulating local advocacy networks to continuously use a petition to propel the Jeju 4.3 events onto the national political stage. The Jeju local council, under the leadership of the Provincial 4.3 Committee, submitted a petition to the legislature in $1993 .{ }^{54}$ This marked the entry of what had been a local Jeju issue onto the national political scene. Kim Young Hoon, a chairperson of the Provincial 4.3 Committee, told me that committee members had learned the importance of petitions from the Taiwanese experience on their official visit to Taiwan in 1993 to study the case and seek advice. ${ }^{55}$ The petition submitted by the local council clearly mentions the Taiwanese experience and contrasts developments in Jeju with those in Taiwan.

However, my study again shows that local activism was an indispensable element in both publicizing and capitalizing on this favorable and noteworthy international precedent. First of all, the Taiwanese case was initially raised by a reporter at the Jemin-I/bo, Kim Jong Min, who saw considerable parallels between the Taiwanese 2.28 events and the Jeju 4.3 events in terms of their characteristics, time and location, perpetrators, number of victims, and aftermath. ${ }^{56}$ Interestingly, the publicity given to the Taiwanese case in South

51. DPP Questions Former Premier Hau's 228 Victim Figures, China Post, 29 Feb. 2012, available at http://www.chinapost.com.tw/taiwan/national/national-news/2012/02/29/333129/ DPP-questions.htm.

52. Kim, The Taiwanese 2.28 Events, supra note 48.

53. Interview with Byun Jeong II, supra note 21; interview with Choo Mi Ae, Congresswoman, in Seoul, Korea (23 May 2011).

54. Jeju Commission, supra note 3.

55. Interview with Kim Young Hoon, supra note 30.

56. Interview with Kim Jong Min, supra note 26. 
Korea was not triggered by or related to a particular event in Taiwan such as the establishment of the commission or the presidential apology. Rather, it was publicized by a concerned local journalist in South Korea who had been involved in the movement and was eager to achieve a breakthrough. It was made possible by the keen eyes of Kim Jong Min, which had been sharply focused on the Jeju 4.3 events as he collected data and interviewed witnesses in the process of writing weekly reports on the Jeju 4.3 issue. ${ }^{57}$ Even though the Taiwanese case did not receive extensive coverage in other national newspapers, one local journalist read an international news article and saw the potential of the Taiwanese case to inspire and guide the transitional justice movement in Jeju. This single international news report could easily have been overlooked among the thousands of other news stories that appeared that day.

After the local Jeju community became aware of the Taiwanese case, local activists engaged in information politics in order to maximize the impact of the Taiwanese example. Kim made the significant move of asking scholars who majored in contemporary Chinese history to analyze the Taiwanese 2.28 events, and then published a series of commentaries comparing the Taiwanese case to the Jeju 4.3 events. ${ }^{58}$ Lee Young Hee, a respected historian, explained that both events had occurred in the late 1940s, immediately after World War II; in both cases systemic and province-wide massacres had been committed by anticommunist governments in the name of counterinsurgency; both events were characterized as communist rebellions instigated by the communist party, which was a major enemy of the state at that time; the truth had been suppressed under consecutive anticommunist regimes; and the number of victims who had been killed was more than 15,000 in both cases. ${ }^{59}$ The stark similarities between the massacres in Taiwan and Jeju initially appealed to many local activists, media representatives, and politicians. This simple information on the experience of a neighboring country would not have been a significant factor in itself, but became useful once it had been strategically studied, understood, and reinterpreted by local activists. With their efforts, the Taiwanese case was no longer an event that had simply occurred in a neighboring country, but an event that was highly relevant to Jeju. In sum, the Taiwanese experience had a substantial impact on the Jeju case because the locals actively sought to use it to their benefit. It was local activists who ensured that the Taiwanese experience had an influence on the South Korean transitional justice process.

57. See Jeju Commission, Hwahae-wa Sangsaeng: Jeju 4.3 Wimeonhoe Hwaldong Bogoseo (Reconciliation and Coexistence: Report on the Activities of the Jeju Commission), at 92 (2008).

58. Lee Young Hee, The Truth about the Taiwanese 2.28 Events, Jemin-ILBo, 2 June 1993.

59. Id.; see also DPP Questions Former Premier Hau's 228 Victim Figures, supra note 55. 


\section{B. International Norms}

Constructivists in international relations have studied international norms, which are "collective expectations for the proper behavior of actors with a given identity." ${ }^{60}$ Scholars suggest that there is a growing norm relating to individual criminal accountability and institutionalized truth-telling about past human rights violations. ${ }^{61}$ This norm is closely related to the development of international human rights norms, since accountability and truth-telling are about the past human rights violations. International norms affect local advocacy networks, assisting in the spread of new ideas and concepts and making previously unimagined options and strategies possible. I found that international human rights norms had a significant impact on the path of transitional justice advocacy in South Korea, especially in the final stage. However, "ideas do not float freely," and international norms need to first be grappled with by local actors, and then undergo a process of interaction with political institutions, civil society, and political culture. ${ }^{62}$

Evidence of the impact of international human rights concepts and norms can be easily identified in the later phase of the advocacy movement. In 1998, several national and international conferences on the Jeju 4.3 events were convened. ${ }^{63}$ The International Conference on Peace and Human Rights in $21^{\text {st }}$ Century East Asia, organized by the Jeju 4.3 Research Institute, was the largest and most influential of these. This conference involved 500 activists and scholars from Taiwan, Japan, and Korea, as well as internationally prominent activists and scholars, including 1996 Nobel Peace Prize Laureate José Ramos-Horta from East Timor, Fazel Randera, a commissioner of the South African Truth and Reconciliation Commission, and a former Japanese

60. Peter J. Katzenstein, The Culture of National Security: Norms and Identity in World Politics 5 (1996).

61. Sriram, supra note 16, at 394; Ellen Lutz \& Kathryn Sikkink, The Justice Cascade: The Evolution and Impact of Foreign Human Rights Trials in Latin America, 2 CHI. J. INT'L L. 1, 2 (2001).

62. Thomas Risse-Kappen, Ideas Do Not Float Freely: Transnational Coalitions, Domestic Structures, and the End of the Cold War, 48 INT'L OrG. 185 (1994), Amitav Acharya, How Ideas Spread: Whose Norms Matter? Norm Localization and Institutional Change in Asia Regionalism, 58 INT'L ORG. 239 (2004).

63. There have been three notable conferences, held by the National Committee for the 50th Anniversary of the Jeju 4.3 Events (28 Apr. 1998), the 50th Anniversary Commemoration Committee for the Jeju 4.3 Events through the Cultural and Academic Projects (9 Apr. 1998), and the Jeju 4.3 Research Institute (21-25 Aug. 1998). See also 4.3 Reporting Team, 4.3 Speaks (Seoul: Jeonyeweon, 1997); Bruce Cumings, The Question of American Responsibility for the Suppression of the Chejudo Uprising (paper presented at the 50th Anniversary Conference on the Jeju 4.3, Tokyo, 1998), available at http://www.iacenter. org/Koreafiles/ktc-cumings.htm; Chang-Hoon Ko, US Government Responsibility in the Jeju April Third Uprising an Grand Massacre-Islanders' Perspective, 8 Jibang Jeongbu Yeongu (Study of Regional Government) 123-140 (2004). 
senator, Den Hideo. ${ }^{64}$ Den Hideo came to prominence in 1973, when he led an international campaign to rescue Kim Dae Jung after he was kidnapped by the Korean Central Intelligence Agency. Den Hideo met with Kim Dae Jung during his visit to Korea for the conference, which also helped to publicize the Jeju 4.3 events. This is another example of an effective strategy-leverage politics—used by local activists. Activists intentionally invited Senator Den to the conference because he was someone who could exert maximum influence over Kim Dae Jung by reminding him of his past promises. ${ }^{65}$

The conference drew not only local but national and international attention to the Jeju 4.3 cause. Seizing on this important opportunity, activists strategically reinterpreted and reframed the Jeju 4.3 events and massacres using the discourse of human rights. This change was timely and important because the human rights discourse began to gain wide currency in South Korean society with the inauguration of Kim Dae Jung, who was known for his lifelong fight for liberal democracy and human rights. In this way the Jeju 4.3 events, which had been conventionally defined as either communist rebellion by the right or democratic uprising by the left, were reframed as a human rights issue. Scholars and activists saw the possibilities for framing the atrocities in terms of the more general and contemporary notion of human rights violations in order to appeal to a general audience. The term "human rights violations" began to be used more frequently after the international conference. It appealed to the national audience, which was not familiar with the Jeju 4.3 events, and therefore in a sense represented a strategic move to reframe the Jeju 4.3 events as a violation of human rights.

The use of the concept of human rights violations also had a further, unintended consequence. By focusing on human rights violations, activists were temporarily freed from the ideologically controversial baggage of the Jeju 4.3 events themselves. When activists spoke of the "mass murder of innocent civilians," the question of whether the dead had really been innocent was always raised, leading to a debate around the ideological nature of the Jeju 4.3 events. ${ }^{66}$ Such debates usually became bogged down in the inconclusive divide between civilians and combatants or active and reluctant participants. When the concept of "human rights violations" was used, on the other hand, greater emphasis was placed on the violators of human rights - the state- and less on the characteristics of the victims and events. ${ }^{67}$ Although human rights abuses by the leftist guerrillas were also

64. Yang Jo Hun, The "Success" of Unprecedented International Events, Jemin-ILBO, 24 Oct. 2011; Yang Jo Hun, Reaffirming the 'Human Rights' Alliance in the East Asia, Jemin-ILbo, 26 October 2011.

65. Interview with Kang Chang II, supra note 32.

66. Kim, Seeking Truth after 50 Years, supra note 2.

67. Id. at 415 . 
raised, the focus was more on state violence, which constituted about eighty percent of the violations. ${ }^{68}$

\section{Pressure from International Civil Society}

International governmental organizations and NGOs are an integral part of the international structure, and scholars have noted the growing role of support from and involvement of international governmental organizations and NGOs in transitional justice processes. ${ }^{69}$ However, my research did not find any evidence of the direct impact of international governmental organizations or NGOs in the South Korean case. One reason for this may be found in the response of Juan E. Mendez, a former President of the International Center for Transitional Justice (ICTJ), when I asked him why the ICTJ did not work in South Korea. ${ }^{70} \mathrm{He}$ observed that the ICTJ usually becomes involved when it receives a request from a government or local NGO-apparently there had been no such request in the South Korean case. His answer suggests one possible mechanism through which international actors influence the establishment of truth commissions. Although international actors are necessary, it is the initial request by local actors themselves that is more important in attracting the expertise and know-how of such international actors. This is consistent with my finding that the experience of neighboring countries is most effective when actively utilized by local actors. Thus, the South Korean experience confirms that two critical international factors-the diffusion effect and pressure from international civil society-were mainly driven by local demands and efforts.

On the other hand, there is strong evidence that Korean-Japanese who were originally from Jeju played a significant role. Recent studies have revealed the importance of diaspora populations in the truth commission process. ${ }^{71}$ Korean-Japanese made three main contributions to the transitional

68. Jeju Commission, supra note 3; Jieun Chang, National Narrative, Traumatic Memory and Testimony: Reading Traces of the Cheju April Third Incident, South Korea, 1948, 86 (2009) (unpublished Ph.D. dissertation, New York University), available at http://gradworks.umi. com/3365697.pdf.

69. See Post-Conflict Justice, supra note 16; Minow, supra note 16, at 126-28, 138; Thomas Buergenthal, The United Nations Truth Commission for El Salvador, 27 VAND. J. Transnat'L L. 497, 542 (1994).

70. Mendez was invited to the talk titled, For One; For All-International Human Rights (with Kathryn Sikkink), which was a part of series of A Great Conversation hosted by the University of Minnesota, 24 Apr. 2007; Mr. Mendez also had informal discussions with faculty members and students in the Dean's Conference Room at the University of Minnesota Law School, 24 Apr. 2007.

71. Laura A. Young \& Rosalyn Park, Engaging Diasporas in Truth Commissions: Lessons from the Liberia Truth and Reconciliation Commission Diaspora Project, 3 INT'L J. TRANSIT'L J.341 (2009); Ezekiel Pajibo, Civil Society and Transitional Justice in Liberia: A Practitioner's Reflection from the Field, 1 INT'L J. TRANSIT'L Just. 287 (2007). 
justice process in South Korea. However, the role of Korean-Japanese should not be understood as a purely international effect but as an internationalized local influence.

First, Japan—specifically, Korean communities in Japan-provided a refuge for people fleeing Jeju during the Jeju 4.3 events, and served as a repository of written records, memories, and alternative discourses. This was crucial, because the South Korean government systematically destroyed any evidence of the Jeju 4.3 events. $^{72}$ Thus, records, memories, and narratives created and maintained in Japan played an important role in the transitional justice movement immediately after democratization in 1987 because little documentation remained in South Korea and victims were still reluctant to talk about the massacres. Activists and scholars therefore relied heavily on materials written in Japan.

For example, in 1957, Kim Seok Beom, a Korean-Japanese originally from Jeju, published a novel, The Death of a Crow, based on the Jeju 4.3 events. Kim also wrote a later novel, A Volcanic Island, which was serialized in a major Japanese newspaper over approximately twenty years. Kim wrote constantly on the theme of Jeju and the massacres. His work was read widely, not only by Korean-Japanese but also by the general Japanese public. In addition, his works were translated into Korean and became popular in South Korea after democratization. ${ }^{73}$ Kim's work had an undeniable influence on a small but significant transitional justice advocacy movement in Japan. In 1963, another important book, A History of the Jeju People's 4.3 Armed Struggle by Kim Bong Hyun and Kim Min Joo, was published in Japan. The authors, who were former communist guerrillas, documented the process of the campaign in detail using extensive interviews with participants in the Jeju 4.3 events who had taken refuge in Japan. This book was important because it was the only historical and nonfictional record written by guerrillas in the period soon after the events took place. ${ }^{74}$

Second, the Korean-Japanese community was also a place where people were able to secretly commemorate the Jeju 4.3 events and perpetuate the memories of the victims through small but public memorial services. On 3 April 1988, several Korean Japanese from Jeju-including writer Kim Seok Beom and former guerrilla Kim Min Joo-held the first public memorial service in Tokyo, and such services later became an annual event. These small

72. Kim, Seeking Truth after 50 Years, supra note 2, at 414.

73. In Search of "People's Peace" in East Asia: On the Crossroads of Historical Experiences between Japan and Korea, Peace Stud. Bull. No. 26 (Peace Studies Association of Japan, Kanagawa Prefecture, Japan), Oct. 2007, at 7, available at http://www.psaj.org/html/ psajnle26.pdf.

74. Bong Hyun Jim \& Min Joo Kim, Jeju-do Inmindeul-ui 4.3 Mujangtujaengsa [A History of Jeju People's 4.3 Armed Struggle], in Jeju Minjung Hangjeang [Jeju People's Uprising] (Arari Research Institute ed. 1988). 
gatherings had a lasting impact on the trajectory of the movement because two university students studying in Japan participated in the memorial services and went on to become leaders of the transitional justice movement in South Korea. Kang Chang II served as a director of the Jeju 4.3 Research Institute and is currently a congressman representing Jeju province; while Kim Myeong Sik published important books on the Jeju 4.3 events and participated in the establishment of the Jeju 4.3 Research Institute. ${ }^{75}$

Third, the Korean-Japanese were actively engaged in the enactment movement in 1999 and worked to empower local activism from the outside. A few prominent figures, such as Seo Seung, a renowned human rights activist, actively participated in the later stages of the movement and represented the victims in Japan. Others organized public lectures, conferences, and memorial concerts to help publicize the Jeju 4.3 events to both the KoreanJapanese and the Japanese general public. All of these activities served as a symbol that the Jeju 4.3 events were not only an issue of local and national importance but were also of international importance. In a sense, Japanese senator Den Hideo's visit to the 1998 international conference was made possible by the persistent activism of the Korean-Japanese.

\section{CONCLUSION}

This article outlined why local advocacy networks, comprising local students and scholars, social activists, and journalists, were the most important actors in the transitional justice process, facilitating conducive domestic and international conditions, taking advantage of the positive factors, and fighting hard against constraints and obstacles. However, these findings have two further implications that extend beyond the South Korean experience.

First, it draws our attention to the role of non-elite actors in shaping transitional justice process. By using social movement theory and transnational advocacy networks theory, this article has moved away from the traditional decision-making model of political elites that has frequently been used by scholars in the past. ${ }^{76}$ The elite model looks at the decision-making process of elite groups and treats the demand for truth and justice from civil society as one of many elements that affect the elites' decision-making process.

75. In Search of "People's Peace" in East Asia, supra note 73, at 7.

76. See generally Huntington, supra note 15; Geoff Dancy \& Steven C. Poe, What Comes Before Truth? The Political Determinants of Truth Commission Onset (paper prepared for presentation at the annual meeting of the International Studies Association Conference, San Diego, California, 22-25 Mar. 2006), available at http://citation.allacademic.com/ meta/p_mla_apa_research_citation/0/9/9/3/2/pages99320/p99320-1.php; Jack Snyder \& Leslie Vinjamuri, Trial and Errors: Principle and Pragmatism in Strategies of International Justice, 28 INT'L SEC. 5, 6 (2003). 
However, by focusing on the decision-makers, this approach neglects the dynamics and history of grassroots advocacy and therefore cannot adequately explain the way in which the demand for truth and justice becomes increasingly effective over time. Moreover, because the characteristics of elites are idiosyncratic, studies are often reduced to an examination of the political environment that leaders face in their decision-making. In addition, a decision-making model sets the prior goals of decision-makers as stability, power, survival, or peace, and approaches truth commissions in terms of their instrumental value in achieving or obstructing these objectives. In such an approach, the intrinsic value of truth commissions and the voices of victims and activists are generally disregarded. Thus, this article's theoretical framework provides an empirically and ethically comprehensive understanding of the process and circumstances behind the transitional justice process.

Second, the South Korean case has a broader implication for the emerging global trend that has been referred to as the "truth commission phenomenon." Since the 1980s, more and more countries have undergone the transition from authoritarianism to democracy, and the recent wave of democratization in the Middle East and Northern Africa suggests that this trend will continue in the twenty-first century. Transitional countries are increasingly expected to address their past human rights violations. To date, thirty-five countries have used such commissions, with five new commissions established in 2009 alone. ${ }^{77}$ In addition, there is an upward trend in the number of years of human rights violations that are being investigated by recent commissions. In other words, the temporal mandate of recent commissions has been expanded considerably. ${ }^{78}$ Some recent commissions have been established to investigate events that took place more than forty years (e.g. Morocco, Kenya, and Togo) and, in extreme cases, 100 years ago (e.g. South Korea). Further, many countries are creating truth commissions at multiple points in time after their transition to democracy. Countries such as Uganda, Uruguay, Chile, and Ecuador have already created their second truth commissions. ${ }^{79}$ In other words, not only is the number of truth commissions increasing, but their function is becoming both more extensive and more intensive.

What explains this growing truth commission phenomenon around the world? One answer may be found in my research on the South Korean case. The impetus is primarily being provided by local actors, who are constantly struggling to make both domestic and international structures favorable to the creation of truth commissions. The space for the phenomenon is opened

77. HaYNeR, supra note 7, at 6.

78. Dancy, Kim \& Wiebelhaus-Brahm, supra note 7, at 57.

79. Truth Commission: Uruguay, United States Institute of Peace, available at http://www. usip.org/publications/truth-commission-uruguay; see website for information on other truth commissions. 
up by their conscious strategic efforts to create and change the domestic and international structures. Structures are not fixed entities but constantly changing environments. Local activists in South Korea have clearly shown that the domestic and international structures-both opportunities and constraints - can be made, remade, and unmade through consistent activism and effective and timely strategies. Sometimes small but innovative first steps such as the 1993 petition movement and the 1960 private investigation by local students can make a big difference. At other times, timely and effective strategies, such as the 1992 strategic announcement of the discovery of the Darangshi cave, local investigative journalism, the introduction of the Taiwanese case to Jeju, and the deliberate use of human rights discourse to overcome ideological divides and draw national attention to the massacres can change the prevailing dynamics and turn a hostile structure into a conducive environment. 